\title{
El auto de fe de 1606
}

\author{
M. ${ }^{2}$ Isabel Pérez de Colosía Rodríguez *
}

\section{EL AUTO DE FE}

La relación del auto de fe de 1606, está dividida en los siguientes siete apartados: Relajados en persona, Relajados en estatua, Reconciliados por la secta de Mahoma, Reconciliados por la ley de Moisés, Reconciliados por la secta Luterana, Penintenciados con abjuración de behementi y Penitenciados con abjuración de levi ${ }^{1}$.

El grupo mayoritario de los procesados en esta ceremonia punitiva es el de los moriscos. Ello nos pone de manifiesto que, a pesar de su expulsión del Reino de Granada, una vez finalizada la Guerra de las Alpujarras, permanecieron en este territorio algunas prolificas sagas de neoconversos, las cuales procurarán mantener su fidelidad al Islam, a pesar de las persecuciones inquisitoriales, muy recrudecidas tras el enfrentamiento bélico ${ }^{2}$. En la distribución espacial de los encausados por mahometismo, queda bien presente que los grupos de mayor relevancia estaban avecindados en Granada y Baza. Por tanto, será en estas ciudades, donde se registre el índice más elevado de moriscos sentenciados.

Dentro de los denominados delitos mayores, los judaizantes ocupan un segundo lugar, según queda reflejado en el cuadro $n .^{\circ} 1$. En él, se patentiza que si los antiguos mudéjares convertidos son objeto de una mayor dureza en esta redada inquisitorial, por el contrario, los criptojudíos disfrutan de una etapa de cierta tranquilidad, después de las constantes persecuciones que sufrieron a finales del siglo $\mathrm{XVI}^{3}$. La política cambiante

Universidad de Málaga.

Archivo Histórico Nacional (AHN), Inquísición, leg. 1953, n. ${ }^{\circ} 31$, s.f.

a Pérez de Colosia Rodríguez, M. ${ }^{a}$ I., "Represión inquisitorial después de la Guerra de las Alpujarras", Baetica, núm. 12 (1989), págs. 215-238.

${ }_{3}$ Ibidem, "Los judaizantes y el Santo Oficio de Granada (1500-1600)" en, Mentalidad e ldeología en el Antiguo Régimen. Actas de la II Reunión Científica de la Asociación Española de Historia Moderna, Murcia, 1993, t. II, págs. 411-418. 
CUADRO 1. TIPOLOGÍA DELICTIVA

\begin{tabular}{lcccc}
\hline Delito & Hombres & Mujeres & Total & $\%$ \\
\hline Islamismo & 26 & 24 & 50 & 71,43 \\
Judaísmo & 2 & 2 & 4 & 5,71 \\
Luteranismo & 1 & - & 1 & 1,43 \\
Bigamia & 3 & - & 4 & 5,71 \\
Estados & 1 & - & 1 & 1,43 \\
Fautoría & 1 & 2 & 1 & 1,43 \\
Hechicería & - & 1 & 5 & 2,86 \\
Moral sexual & 4 & 2 & 2,14 \\
Absueltos & 1 & 31 & 70 & 100,00 \\
\hline Totales & 39 & & &
\end{tabular}

de la Corona, respecto a esta diáspora, se evidencia en que, según los años, varía mucho el número de conversos que salen en los autos de fe; hecho íntimamente relacionado con los intereses socioeconómicos de los monarcas reinantes y del mismo pueblo de los cristianos viejos ${ }^{4}$.

El tercer delito mayor es el luteranismo que, como siempre, resulta el menos testimonial, numéricamente hablando. Sólo un caso será sentenciado en este auto de fe. El resto de los condenados, que no lo fueron por herejia, son poco representativos pero algunos muy interesantes.

De los procesados, dos lograron quedar libres de causa: un regidor de Ronda, Diego Núñez Álvarez, y la mujer de otro caballero regidor del mismo municipio, Doña Inés de Gamasa. La categoría social de la dama destaca del resto de las mujeres encausadas, por ser la única que tenía el privilegio de detentar el título de Doña. Ambos procesados pertenecían a la oligarquía rondeña al formar parte de la clase concejil, aunque ello no les libraría de pasar por las cárceles del Santo Oficio. A pesar de que sus causas fueran resueltas sin cargo alguno, esto no obstó para que hubieran de responder ante el tribunal de una serie de acusaciones y demostrar la falsedad de las mismas.

Las sentencias leídas han sido sintetizadas en el cuadro n..$^{\circ}$. En números naturales tenemos que son diez los condenados a la pena máxima: la relajación. Cuatro lo serían en estatua, dado que las dos mujeres judaizantes fallecieron antes del auto, en tanto que los otros encausados

4 Contreras Contreras, J., “Hipótesis y reflexiones: la minoría judeoconversa en la Historia de España», en Mentalidad e Ideología en el Antiguo..., págs. 37-56. 
El auto de fe de 1606

CUADRO 2. SENTENCIAS EMITIDAS

\begin{tabular}{lcccc}
\hline Condenas & Hombres & Mujeres & Total & $\%$ \\
\hline Relajados & 4 & 6 & 10 & 14,28 \\
Reconciliados & 21 & 20 & 41 & 58,57 \\
Penitenciados & 13 & 4 & 17 & 24,29 \\
Absueltos & 1 & 1 & 2 & 2,86 \\
\hline Totales & 39 & 31 & 70 & 100,00 \\
\hline
\end{tabular}

eran moriscos que habian conseguido huir antes de ser apresados. Los sentenciados a relajar en persona, todos ellos neoconversos, fueron dos varones y cuatro mujeres. Dos de las féminas se libraron de las llamas porque, en última instancia, pidieron audiencia para confesar sus culpas $y$, por tanto, regresaron a las cárceles del tribunal.

La primera de las mujeres, Maria de Torres, estaba casada con el jurado de Baza, Juan Adam, uno de los moriscos más ricos de la ciudad, que se había desposado con ella no obstante no pertenecer a su círculo social. A ésta se le aplicó el tormento, pero lo superó sin delatar a nadie. Cuando ya se hallaba en el cadalso, pidió audiencia, en la cual denunció a Ambrosio Ruiz como el «maestro y dogmatiçador" de los moriscos, que le enseñó los principios coránicos. La otra condenada era una del clan de los Cavedo, con vecindad en Caniles, apresada dos años antes del auto. Fue votada a tormento it caput alienum, donde puso a prueba su fortaleza física y espiritual, pues no se logró que confesase ni delatase a sus compañeros de religión. Sin embargo, cuando estaba esperando oír su sentencia en el escenario del auto y vio muy de cerca la muerte en la hoguera, no pudo resistir y habló ${ }^{5}$.

El mayor número de sentencias corresponde a los reconciliados, que alcanzan la cifra de 41 , de las cuales el $92 \%$ recayeron sobre los moriscos. A mucha distancia les siguen los penitenciados y, de los 17 condenados, el $76 \%$ lo eran por causas varias, el resto lo serán por islamizantes. Por último, tenemos las dos personas cuyos procesos fueron sobreseídos.

Respecto a la distribución por sexos, el porcentaje de mujeres y hombres juzgados es casi idéntico, con un leve ascenso correspondiente a los segundos (gráf. 1).

La información que aporta el documento sobre el estado civil de los reos, sólo consta en el elemento femenino, y su recuento nos muestra

5 AHN, Inquisición, leg. 1953, n. ${ }^{\circ} 31$, s.f. Causa nos. 4 y 6. 


\section{Gráfico 1}

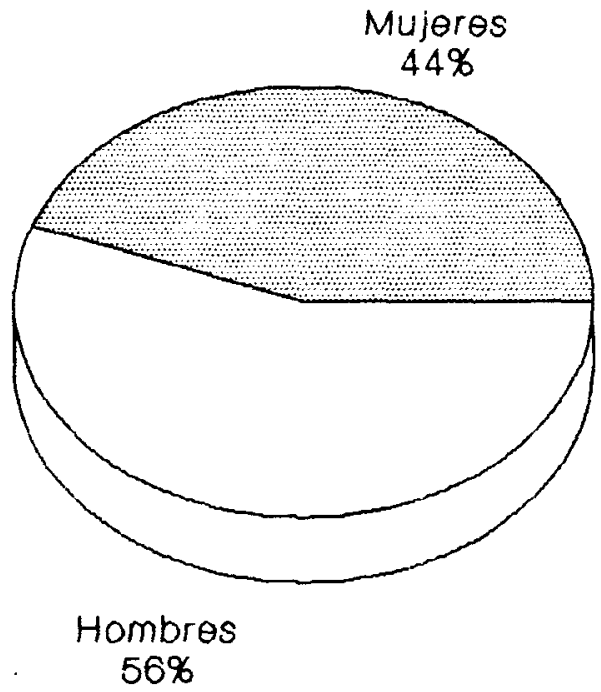

Gráfico $n^{\circ}$ 1. Distribución porcentual por sexos.

que las casadas superan en mucho a las solteras y viudas (gráf. 2). Aunque no se registra el estado civil en los varones, de forma indirecta lo sabemos porque, cuando en la relación se hace referencia a las casadas, siempre queda especificado el nombre del cónyuge.

La Inquisición solía apresar a familias completas y, por tanto, las delaciones recaian en primer lugar sobre los parientes más cercanos: esposos, hijos, hermanos, cuñados, primos, etc., como sucede en este auto con los islamizantes. En un elevado porcentaje, encontramos que en esta ceremonia punitiva, fueron sentenciadas muchas mujeres moriscas con sus maridos y otros parientes. Aquellos miembros de su linaje, cuyos procesos aún no habían concluido en ese año, escucharán las resoluciones emitidas por los inquisidores en el auto de 1608.

Además de confiscar a todos los reos sus bienes, e imponerles el hábito o sambenito, se les aplicaron otras condenas. Entre ellas predomina la cárcel perpetua y, en menor número, la cárcel por un tiempo determinado (gráf. 3). De los reos enviados a prisión, encontramos varios 


\section{Gráfico 2}

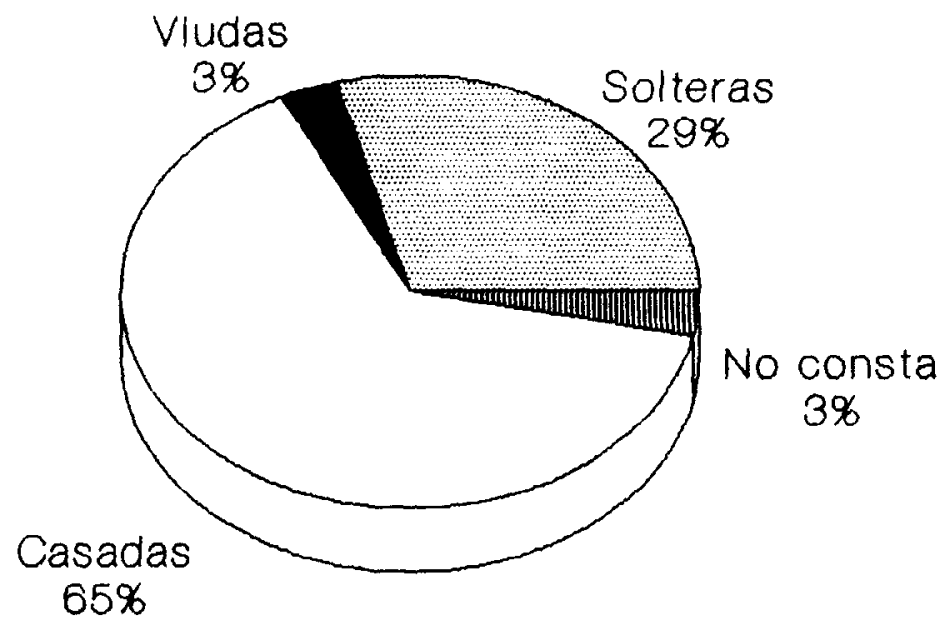

Gráfico n. ${ }^{\circ}$ 2. Estado civil de las procesadas.

informes dados por el alcaide de la misma, en donde da cuenta, de forma individual, de cómo se comportaba el recluso.

Entre ellos es de destacar el caso de Lucrecia Venegas. En su informe queda especificado que fue votada a tormento, en el cual «se le dieron tres bueltas a los braços y se tendió en el potro, aunque no se le apretó ningún garrote». El alcaide dice de ella que cumplía la sentencia con humildad y vivía "quieta y honestamente". Muy curioso es el emitido sobre Isabel Adam, viuda del morisco relajado Juan García Gualit o Volite. Acerca de ella corrían una serie de rumores "de que tratava en amistad deshonesta con un preso", pero no se pudo verificar. No obstante, se la reconvino y con ello se terminaron las habladurías. Para evitar posibles reincidencias, el alcaide aconsejó que, por "ser moça, y de buen parezer y viuda", deberían recogerla sus deudos, porque éstos la "pondrán en estado, y se obviarán los ynconbenientes que se podrán seguir de estar 
Gráfico 3

Cércel

Caxili Carcel perpetua

[Caleras

$=$ Azotes

Euin Penas pecunlerias

[ Reclusión monasterio

Verguenza públlce

Destlerro

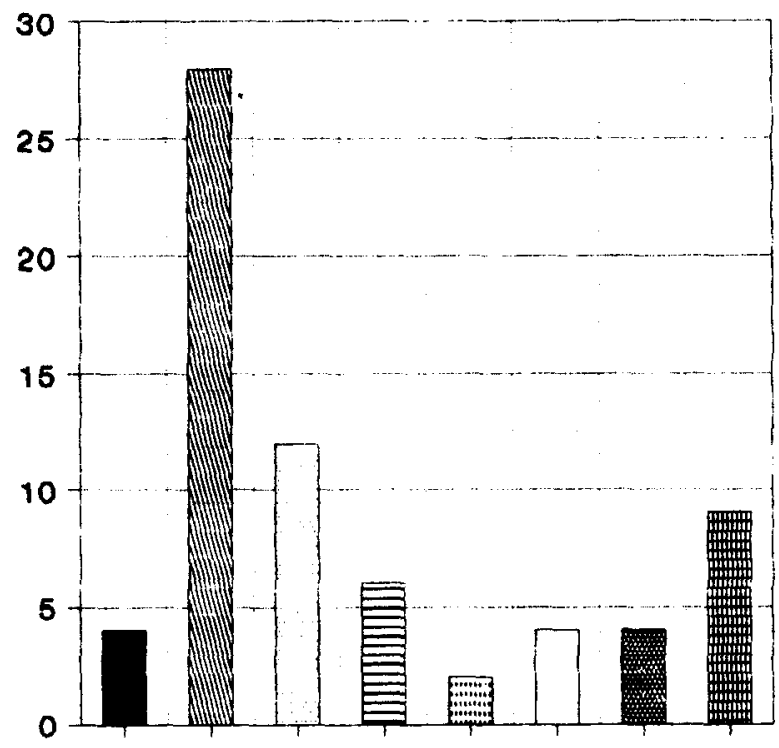

Gráfico n.⒊ Penas impuestas.

sola en la dicha carçel». Parece ser que la prisión no era un obstáculo insalvable para los lances amorosos ${ }^{6}$.

En segundo lugar tenemos las condenas a galeras. Ha de tenerse en cuenta que, en numerosas ocasiones, las penas de cárcel y remo son sufridas por una misma persona, pues sobre muchos de los culpados recaía el castigo adicional de que los primeros años de prisión - de tres a seis según los casos-, tenían que cumplirlos en las galeras, librándose de tal castigo sólo los enfermos, por motivos obvios.

Durante la Edad Moderna, las Reales Galeras de España estaban muy necesitadas de remeros. La dureza y el peligro que encerraba tal trabajo, hacía que nadie quisiera realizarlo y, por tanto, sólo pudiera cubrirse a base de condenados, considerado este castigo corporal como uno de los más duros. Con el fin de paliar la carencia de brazos para los remos, la

\footnotetext{
6 Ibidem, leg. 1952.1, s.t.
} 
Gráfico 4

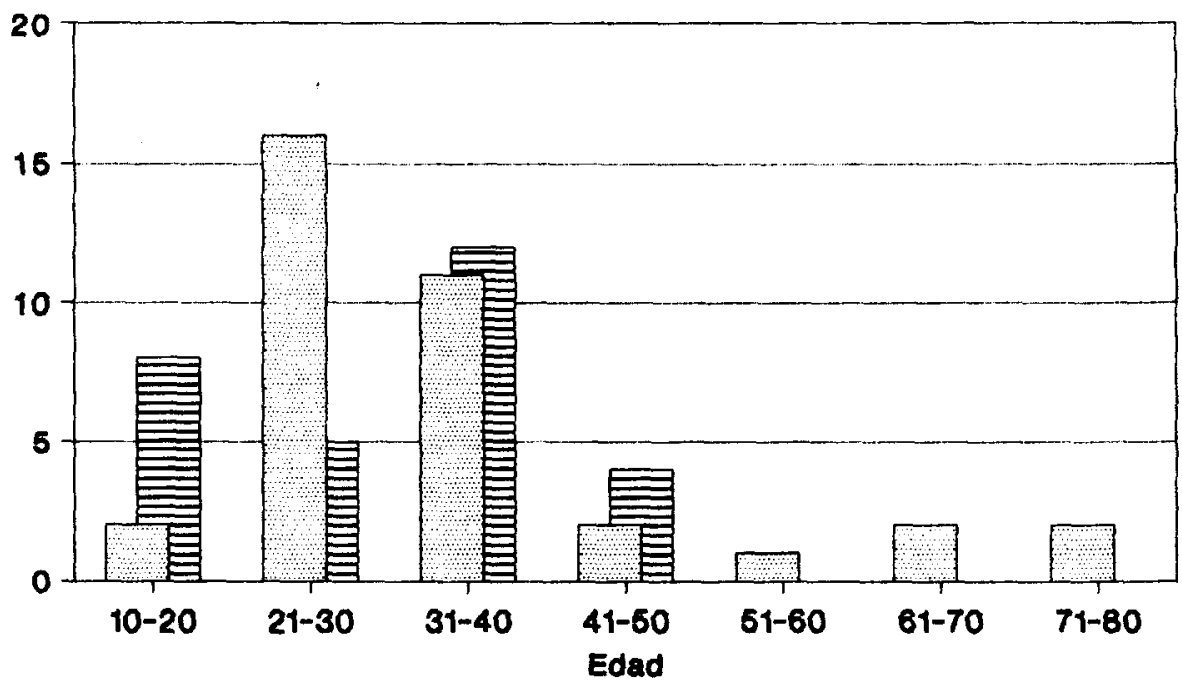

\section{Hombres $\Longrightarrow$ Mujeres}

Gráfico n. ${ }^{\circ}$. Edad de los procesados.

Corona instará al tribunal del Santo Oficio que, siguiendo el mismo procedimiento al uso de la justicia real, sentenciase a sus condenados a galeras.

El destierro de las ciudades, villas y lugares donde residiese el convicto, o de las tierras jurisdiccionales del tribunal, oscilaba entre uno y cuatro años. No obstante, algunos procesados lo fueron a perpetuidad, tal y como consta en el curioso y complicado caso de Inés Arraval. Igualmente será desterrado a perpetuidad «de la costa de la mar y çinco leguas alrrededor" el berberisco de 17 años, Francisco de Trigueros, avecindado en Málaga. El joven, a los pocos meses de haber sido bautizado a petición propia, se embarcó en el puerto malagueño para regresar a Berbería, a fin de poder practicar libremente el islamismo en este país. Su mal sino, hizo que por soplar vientos contrarios, el barco tuviera que regresar a puerto y cayera en manos de la Inquisición. Además del destierro, sería sentenciado a servir en un monasterio durante tres años. 
La reclusión en un monasterio o convento, las penas pecuniarias y, como es lógico, las galeras, únicamente recayeron sobre los varones. La flagelación será aplicada públicamente tanto a hombres como a mujeres. A los primeros, les dieron entre 200 y 100 azotes, siendo todos fugados de las cárceles inquisitoriales; en tanto que a las féminas se les inflige el castigo de 100 , a una por hechicera y a las otras dos por revocantes y perjuras ${ }^{7}$. De los varones, sólo recibe 100 azotes un esclavo, a quien una vez aplicada la pena se le devuelve a su amo. Seguramente no le quisieron dar un castigo más duro para no dañarle físicamente, pues esto a quien realmente perjudicaba era a su propietario.

La edad de los procesados abarca desde los 13 hasta los 74 años (gráf. 4). Entre los hombres predominan los de 21 a 40 años. En tanto que en las mujeres, será de los 31 a los 40 , y a partir de los 50 años no se dan más casos. También es de señalar la existencia de ocho jóvenes menores de 20 años.

\section{TIPOLOGIA DELICTIVA}

En primer lugar, y de manera muy destacada, tenemos a los moriscos, que representan el mayor porcentaje de los procesados por herejía, ya que suponen un $71 \%$ frente al resto de los delitos (gráf. 5). De nuevo encontramos una fuerte represión sobre esta minoría disidente, que permaneció en las tierras del Reino de Granada a pesar de las estrictas órdenes decretadas por Felipe II. La subida al trono de su sucesor, no sólo no facilitó la pervivencia de los signos de identidad de los moriscos, sino que recrudeció su persecución, como puede comprobarse en los autos de fe de 1606 y 1608, celebrados poco antes de su definitiva expulsión del territorio peninsular ${ }^{8}$.

El mayor colectivo de neoconversos será capturado en Baza, donde el clan de los Cavedo se convertirá en el eje de las redadas. En segundo lugar tenemos la capital granadina, ciudad en la que encontramos familias entrocadas con los Cavedo, a cuyo frente estaba Ambrosio Ruiz, casado con una de las mujeres de la saga de Baza. Este personaje sería el alma del rebrote islámico habido en Granada y Baza, pues de él los inquisidores dicen, textualmente, que sfue el alfaquí y dogmatiçador de toda la com-

7 Ibidem, leg. 1953, n. ${ }^{\circ} 31$, s.f. Los hombres son las causas 34,43 y 53 . A las mujeres corresponden las 61,66 y 67 .

в GIL SANJUÁN, J., "Ofensiva final antimorisca de la Inquisición Granadina", Baetica, núm. 12 (1989), págs. 187-196. 


\section{Gráfico 5}

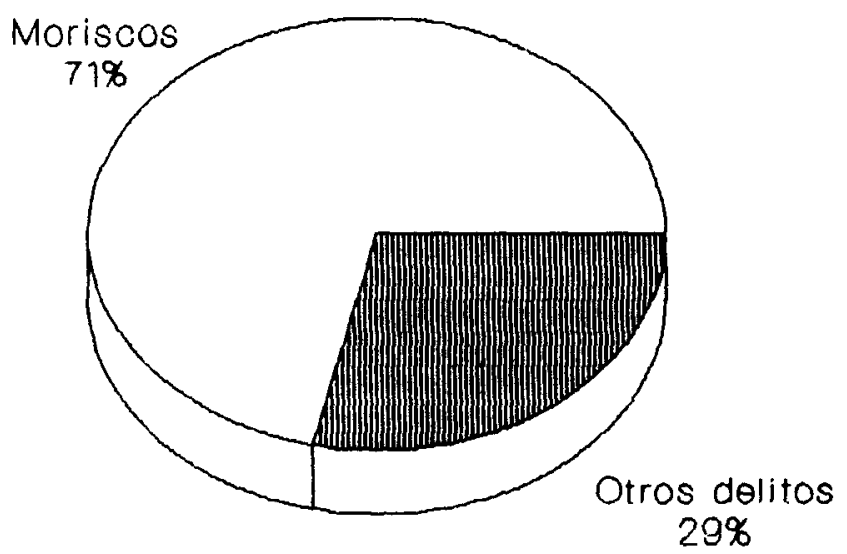

Gráfico $n{ }^{\circ} 5$. Tipología delictiva.

plicidad desta relación de los de la seta de Mahoma, y que les leyó a todos el libro del Alcoram de lo cual fue testificado por treynta testigos" 9 .

El tema de los alfaquíes, ya preocupaba mucho a principios del siglo XVI. El profesor Gil Sanjuán hace un estudio sobre el informe que el doctor Lorenzo Galíndez de Carvajal redactó, en 1526, para presentarlo en la Junta de la Capilla Real. En su escrito enumera una serie de puntos que consideraba fundamentales para lograr la aculturación socio-religiosa de los moriscos. Entre las diversas claúsulas, todas ellas muy representativas del problema existente con los mudéjares convertidos, el documento reseña lo siguiente respecto a los líderes religiosos:

"Que los alfaquies sean exterminados y echados fuera de todo el Reino de Granada, y se vayan a vivir a Castilla o a otras partes, y lo mesmo de cualquier otro dellos que sea sabio o domatizador en su seta, porque apartados de la conversaçión de los domatizadores, poco a poco olvidarán su mala creençia. $Y$ a estos domatizadores se les había de poner

9 AHN, Inquisición, leg. $1953, n .^{\circ} 31$, s.f. Causa n. 10. 
pena de fuego, la cual se había de executar en ellos irremisiblemente, siendo primero amonestados" ${ }^{10}$.

Ambrosio Ruiz, condenado a relajar, había logrado huir antes de ser apresado, por lo cual la sentencia se cumplió en efigie. Sin embargo, su esposa, Isabel de Cavedo, y su hija no consiguieron escapar y salieron en la ceremonia punitiva. La primera fue votada a reconciliación en forma, con confiscación de bienes, hábito y cárcel perpetua. Su hija, que en el momento del auto tan sólo tenía 14 años, fue asimismo reconciliada pero, en consideración a su edad, no sufrió otra pena, además el tribunal dictaminó que una vez acabado el auto se le quitase el sambenito. Otro factor que influyó en dictar una sentencia más leve, consistió en que la joven testificó contra muchos moriscos, a quienes conocía perfectamente por haber estado con ellos en las Juntas que su padre, en funciones de alfaquí, celebraba en la casa.

En Baza, el grupo familiar de los Cavedo fue objeto de un drástico acoso inquisitorial, siendo apresados varios matrimonios con sus hijos, contando estos últimos entre los 14 y 16 años en el momento del auto, lo cual quiere decir que serían muy pequeños cuando les encarcelaron, un año o más antes de su celebración. No sólo los Cavedo cayeron en las redadas inquisitoriales, pues otras familias también sufrieron la misma suerte. Muchas de éstas, estaban entroncadas con los Cavedo, dado que la saga se había ramificado por otros lugares más o menos cercanos, como Caniles y, por supuesto, Granada, ciudad en la que se asentaría Isabel de Cavedo al contraer nupcias con el alfaqui Ambrosio Ruiz. Todos ellos siguieron muy relacionados a pesar de las distancias, asistiendo indistintamente a las Juntas celebradas en Granada y en Baza. Esta última localidad con mucho más protagonismo que la primera.

Dichas congregaciones tenian como finalidad el mantener vivas las creencias de sus antepasados. En líneas generales, consistían en reuniones efectuadas en las casas particulares de los moriscos, pues el hogar resultaba el lugar más idóneo para prácticar el culto y mantener vivas las creencias religiosas. Por temor a ser delatadas al Santo Oficio, las asambleas eran llevadas a cabo en el más riguroso de los secretos, como se evidencia en muchas testificaciones. Entre las condiciones que se imponía a los asistentes, estaban las de que no hablasen con nadie acerca de las personas reunidas en ellas y sobre los temas que trataban.

10 Gil Sanjuán, J., «El parecer de Galíndez de Carvajal sobre los moriscos andaluces (Año 1526)", Baetica, núm. 11 (1988), págs. 385-401. 
En las Juntas se leía el Corán, al tiempo que se procedía a instruirles en todo lo referente a las ceremonias musulmanas, preferentemente en la forma ortodoxa de hacer el guado o guadoc y la zalá. El ayuno de la Pascua del Ramadán era aconsejado constantemente, al igual que los rezos de frases rituales tomadas del Corán. Las más repetidas eran las transcritas por los inquisidores como las del Handululey (Alabado sea Dios), Colalaguahat (Dí, Dios es único) y, en menos ocasiones, la del Virmelay (En el nombre de Dios). Las reuniones también servian para relacionarse unos con otros, e incentivarse mutuamente en las prácticas religiosas, intercambiándose impresiones de cómo cumplian sus preceptos ${ }^{11}$.

Algunos de sus ritos y costumbres manifestaban su condición de islamizantes $y$, por ende, propiciaban las denuncias de los cristianos viejos al temido tribunal. Entre éstos, es de destacar su dieta alimenticia, así como el comer carne los Viernes, ayunar durante la luna del Ramadán o antes de la celebración de unos esponsales.

Una de las prácticas más representativas en todas las religiones es la ceremonia del entierro. La musulmana tiene unas connotaciones muy peculiares, que se llevaban a cabo dentro de un estricto ambiente familiar, por miedo a ser delatados por sus convecinos. No obstante, las denuncias solian provenir de sus propios correligionarios que, cuando eran encarcelados por la Inquisición, fácilmente se les soltaba la lengua al darles unas vueltas de mancuerda, sistema coercitivo que se aplicó en bastantes casos.

Así acaeció a la vecina de Granada, María Ruiz, casada con el sastre baztetano Miguel López, procesado junto con ella en 1606. A ésta la acusaron de «amortajar a un niño con çeremonia, lavándole todas las partes del cuerpo, y ynvocando a Mahoma para que llevase su ánima al çielo» ${ }^{12}$. La Inquisición, a fin de impedir todo acto de carácter musulmán, perseguía a las amortajadoras, en casi su totalidad mujeres, que con sus lavados purificaban los cuerpos de los difuntos ${ }^{13}$. En las minorías disidentes, el elemento femenino era quien mejor conservaba los rituales familiares, teniendo gran protagonismo en bodas, bautizos y entierros. Su valor y el

\footnotetext{
11 Longas, P., La vida religiosa de los moriscos. Estudio preliminar de Darío Cabanelas. Granada, Ed. Servicio de Publicaciones de la Universidad de Granada, 1990.

${ }_{12}$ AHN, Inquisición, leg. 1953, n.०31, s.f. Causa n. 12.

13 VINCENT, B., "Las mujeres moriscas", en Historia de las mujeres. Del Renacimiento a la Edad Moderna. Madrid, Ed. Taurus, 1992, págs. 585-595 y "La familia morisca", en Minorias marginadas en la España del siglo xvı. Granada, Ed. Diputación Provincial de Granada, 1987, págs. $7-29$.
} 
convencimiento de seguir la religión verdadera, hizo que sufriesen el tormento con entereza, sin delatar a sus compañeros, seguidores de Mahoma.

El segundo delito mayor, que aparece en la relación, es el de judaizantes. Numéricamente hablando, va muy por detrás de los islamizantes, pues tan sólo suman cuatro casos: dos mujeres, condenadas a relajar, y dos varones que lo fueron a reconciliación en forma. Nos encontramos en un momento en que los conversos no estaban en el punto de mira del Santo Oficio de Granada.

Las sentencias a relajar se cumplieron en sendas efigies, dado que las reas eran ya difuntas cuando se celebró el auto. Ambas, avecindadas en ciudades donde existía un comercio pujante: Granada y Antequera, pertenecían al mundo mercantil, pues sus respectivos esposos desempeñaban los oficios de corredor y mercader de seda. Las acusaciones que pesaron contra ellas fueron las de que seguían la ley de Moisés, guardaban los sábados y practicaban los ayunos de judíos «de todo el día hasta la noche, salida la Estrella, y el de la Reyna Esthern; además de rezar las oraciones propias de esta religión, cumplir con sus ceremonias y practicar el proselitismo entre sus familiares y amigos, dado que las mujeres eran quienes transmitían con más voluntad los preceptos de la ley de Moisés ${ }^{14}$. Una de las judeoconversas, María de Palma, cuando estaba uen el artículo de la muerte, mandó que después de muerta la lavasen y amortajasen con camisa y lienço nuevo" ${ }^{15}$. Su defunción no la eximió de "que fuese condenada su memoria y fama, y sus huesos exhumados y quemados".

A Elvira Sánchez de Guzmán la delataron no sólo por practicar los ritos ya enumerados, sino también porque «rreçivía limosna de otros cómplices para que ayunase por ellos, y que enseñó la dicha ley a sus hijas $y$ dos oraciones judaycas, que la una comiença por el ayuno de mi boca y la otra alçaría yo mis ojos al señor» ${ }^{16}$. Se encontraba enferma cuando la apresaron, motivo por el cual quedó recluida en casa de un familiar de la Inquisición ${ }^{17}$. Al domicilio de quien ocupaba una de las familiaturas de

\footnotetext{
14 García CARCEL, R., "Las mujeres conversas en el siglo XV"», en Historia de las mujeres..., págs. 597-615.

is AHN, Inquisición, leg. 1953, n. ${ }^{\circ} 31$, s.f. Causa n. ${ }^{\circ} 7$.

16 Ibidem. Causa $n .{ }^{\circ} 8$.

17 Los familiares realizaban varias funciones bien definidas por el tribunal granadino. Entre ellas, estaba la de custodiar a aquellas personas que el Santo Oficio, tras haber recibido algunas denuncias, determinaba que fuesen apresadas. Las competencias de los familiares se ampliaban en casos necesarios, como el convertir sus propios hogares en prisión momentánea para casos específicos.
} 
Antequera, se allegaron el comisario y el notario del Santo Oficio para tomarla declaración, dado que su estado de salud hacía temer un rápido desenlace, como así acaeció, pues fallecería antes de poder trasladarla a las cárceles inquisitoriales granadinas. Tras su muerte, la causa prosiguió hasta ser sentenciada a relajar en estatua.

Los dos judeoconversos reconciliados, de profesión uno mercero y el otro mercader, ambos oriundos de Portugal, estaban avecindados, respectivamente, en Málaga y Vélez Málaga, ciudades costeras con un mercado muy desarrollado a todos los niveles, nacional e internacional ${ }^{18}$.

Uno de éstos, Diego Núñez, fue testificado por un portugués, quien «depuso que le avía querido enseñar la ley de Moysén, diçiendole que no avía de creer en Jesuchristo nuestro Señor, ni en nuestra Señora la Virgen María, ni en sus sanctos, ni en las imágines, y que era peccado en la dicha ley comer ave que no fuese degollada, conejo, liebre, toçino, ni pescado que no tubiese escama, y que avía de ayunar un día grande, sin comer ni bever en todo él hasta la noche» ${ }^{19}$. Otros testigos afirmaron que los viernes y los sábados se ponía camisa limpia, además de que no quería tener representaciones religiosas en su casa. Al aplicarle el tormento confesó que había judaizado durante siete años, rezando los salmos sin el gloria patri, leyendo las biblias en romance, y cumpliendo todo el ritual judaico. A pesar de haber delatado a otros judeoconversos, los inquisidores dictaminaron su encarcelamiento a perpetuidad.

El tercer delito mayor es el luteranismo, y el único caso condenado en 1606 por tal herejia, corresponde a un extranjero, el flamenco Juan de Ambers, natural de Amberes y avecindado en Málaga. Al tratarse de un joven de 21 años de edad, se le designa un curador para que le aconsejase durante el proceso. Éste fue acusado por tres testigos de ciertas afirmaciones heréticas, como el que en la sagrada forma «no estaba Dios", que no era necesaria la confesión y "que la cruz en que Christo nuestro Señor murió no era de provecho».

En la primera audiencia, dijo "que çiertos ingleses le enseñaron que los frayles y clérigos eran malos, y que el Papa no podía perdonar los peccados, y que no estava Dios en la hostia, y que a sólo Dios avían de confesar los peccados y no a los hombres, y que no avía de adorar las cruçes ni imágines, y podía comer carne en Viernes y en días prohibi-

18 Dominguez Ortiz, A., La clase social de los conversos en Castilla en la Edad Moderna. Granada, Ed. Servicio de Publicaciones de la Universidad de Granada, 1991.

${ }_{19} \mathrm{AHN}$, Inquisición, leg. $1953, n .^{\circ} 31$, s.f. Causa $n .^{\circ} 50$. Por eliminación de los alimentos prohibidos, podemos aproximarnos al conocimiento de cual era la dieta de los judeoconversos. 
dos» ${ }^{20}$. Aseguró que todas las ideas expuestas se las enseñaron estando en España, con lo cual se constataba que los británicos aprovechaban sus estancias en la Península, generalmente por motivos mercantiles, para hacer proselitismo entre aquellos que estaban más cerca de su ideología por ser foráneos. Juan de Ambers fue votado a reconciliación en forma $y$, para que aprendiese las verdades del catolicismo, le sentenciaron a que durante dos años viviese en un convento, pero allí no estaría de forma gratuita, ya que tendría que trabajar en «obras serviles», vistiendo el consabido hábito.

Los penitenciados con abjuración de levi son, en su mayoría, condenados por delitos que atañen a la moral sexual y a la hechiceria. Cuatro fueron los sentenciados por bigamia: tres hombres y una mujer.

Entre los varones tenemos un soldado de la guarnición de Melilla, presidio donde contrajo matrimonio, pero posteriormente, al regresar a Baza, volvió a casarse aunque vivía su primera mujer. No era caso raro la existencia de personas que al ausentarse de su lugar de origen durante un tiempo, tomasen esposa donde residiesen eventualmente. Cuando regresaban, no sólo iban sin su consorte, sino que también ocultaban su existencia, contrayendo nuevas nupcias en su pueblo natal.

Tanto el militar como los otros dos bígamos serán condenados a cinco años de galeras y "sacados a la vergüença por las calles públicas» con las insignias de casados dos veces ${ }^{21}$. Uno de ellos, Pedro de Ojeda, huyó de la cárcel pero volvió a ser apresado, motivo por el que se le dieron 200 azotes. Pena aplicada a los prófugos, y servía para disuadir a aquellos que tuvieran in mente huir de las cárceles inquisitoriales.

Ana de la Cruz, casada con un vecino de la villa de Aguilar, volvió a celebrar matrimonio en Málaga cuando aún vivía el aguilarense. La sentencia consistió en salir a vergüenza pública, además de ser desterrada por cuatro años de Málaga y Aguilar ${ }^{22}$.

Todos los condenados por esta causa alegaban que habían tenido noticias del fallecimiento de sus consortes y, en ocasiones, llegaban a aportar testigos falsos ante las autoridades pertinentes. El Derecho penal castigaba a aquellas personas que contraian matrimonio en vida de su anterior cónyuge, pero en la Edad Moderna este delito pasó a ser de

Ibidem. Causa $n .^{\circ} 51$.

21 Ibidem. Causas nos. 57,58 y 59 . Las insignias de estar condenados por delito de bigamia, solían consistir en pintar en la coroza un hombre entre dos mujeres, en el caso de los varones, o viceversa cuando era aplicado en las féminas.

22 Ibidem. Causa n. ${ }^{\circ} 60$. 
jurisdicción inquisitorial, no sin que tal competencia diese lugar a una larga controversia con la justicia secular. Entre otras razones, porque esta última consideraba que el Santo Oficio dictaba unas sentencias tan leves que no disuadian al pueblo de cometer tal delito ${ }^{23}$.

Dentro de esta tipología delictiva, tenemos el caso de «Fray Manuel de Santa María, frayle profeso de nuestra Señora de la orden del Carmen, presbítero, natural de Lisboa". El clérigo se avecindó en Guadix, donde se desposó. Su condena consistió en privarle, a perpetuidad, «del uso y exerçiçio de todos los sacros órdenes", circunstancia que propició el poder enviarlo a galeras durante cuatro años. El resto de su vida permanecería recluido en un convento de su orden ${ }^{24}$.

La liberalidad que tuviese un individuo en su forma de pensar sobre la moral sexual podía ser también motivo de persecución. Así le acaeció al hortelano de la villa de lllora, Pedro Rodríguez, por opinar «que no era peccado mortal tener acçeso carnal con una muger soltera pagándoselo» ${ }^{25}$. El reo afirmó que tal apreciación se debía a que así lo había oído comentar desde niño, lo cual indica que la mentalidad de la época giraba en este sentido. El propio tribunal no consideró un grave delito poner precio a la fornicación, ya que la sentencia consistió en que por un año se desterrase voluntariamente de su villa. De hecho, en el siglo XVII se favoreció la existencia de las mancebías, dado que el fomento de la prostitución estaba dentro de la política llevada a cabo contra la homosexualidad del varón ${ }^{26}$.

El parecer que se tenía sobre el denominado estado de casado, era muy tenido en cuenta por el Santo Oficio, que defendía el sacramento como un vínculo sagrado e indisoluble, sobre el cual no cabía expresar ningún criterio que fuese en su detrimento. Por hablar sin respeto del matrimonio, sería encarcelado un curtidor de la ciudad de Vélez, porque estando ofendido con su esposa, dijo de forma airada "que votava a Christo que valia más estar amançebado que casado". Expresión que

23 Gacto, E., "El delito de bigamia y la Inquisición española», en Sexo barroco y otras transgresiones premodernas. Madrid, Alianza Ed., 1990, págs. 127-152. Ya en las Partidas se condenaba a los bígamos a la confiscación de bienes y destierro por cinco años. Así mismo, el Derecho regio ordenaba herrar a los varones convictos con una "q" en la frente; si bien, no parece claro que existiese un sólo signo de la marca grabada a fuego. Carlos I añadió la pena de galeras y Felipe II abolió el castigo de que fuesen herrados, pero impuso el de la vergüenza pública.

${ }^{24}$ AHN, Inquisición, leg. 1953, n. ${ }^{\circ} 31$, s.f. Causa n. ${ }^{\circ} 56$.

25 Ibidem. Causa n. ${ }^{\circ} 62$.

${ }^{26}$ Clavero, B., "Delito y pecado. Noción y escala de transgresiones", en Sexo barroco y otras transgresiones..., pág. 79. 
agravó al añadir «que el diablo avía inventado e ynstituydo el matrimonio, que no Dios». Las irreverencias, que tenían ribetes heréticos, las justificó el interpelado alegando que las había dicho porque estaba enfurecido con su esposa. Argumento que debió ser admitido en parte, pues sólo se le sentenció a que por un año se desterrase voluntariamente de la ciudad de Vélez ${ }^{27}$.

No obstante el respeto al estado de casado, era considerado mucho más perfecto el de religioso. El expresarse de forma contraria hizo que fuese denunciado al tribunal un aceitero trancés de 68 años, avecindado en Granada, por decir que el "mejor estado es el de los buenos cassados". Ante el tribunal adujo que lo había dicho por ignorar que la Iglesia enseñaba lo contrario. Debió ser tenido en cuenta su desconocimiento del tema, o tal vez tuvieron en consideración su edad, pues el veredicto consistió en que saliese en auto público en forma de penitente y que en él abjurase de levi ${ }^{28}$.

Más dura fue la condena que recayó sobre un trabajador rural, vecino del lugar de Dúdar. El vivir en un medio campesino y tener que pasar largos espacios de tiempo en solitario para realizar las tareas agropecuarias, le llevó al convencimiento de «que no era peccado tener acçeso carnal un hombre con otro, estando trabajando en el campo". Su tosquedad se puso de manifiesto cuando le dijeron que se fuese a confesar, que si no le denunciarían al Santo Oficio, a lo que el campesino «rrespondió, poniendo la mano en la avertura delantera de los gregescos, aquí tengo yo la Inquisición" ${ }^{29}$. Confesó que habia hablado con imprudencia, pues él bien sabía que el "acçeso nefando era peccado". Tal declaración no le libraría de salir a vergüenza pública, ser desterrado de Dúdar durante medio año obligatorio y otro año voluntario.

No obstante, y seguramente debido a la rudeza e incultura del interfecto, la sentencia fue leve, pues la sodomía se perseguía con gran dureza. Este delito competía a la justicia real que, desde el Medievo, condenaba a muerte a quienes la practicaban. Ya en el Fuero de Béjar se legisla: "De varón que fornica con otro. Qui fuer preso en sodomítico pecado, quemarlo". Más concreto no puede ser. Tomás y Valiente nos ilustra con otras muchas citas de disposiciones legislativas, los castigos ejemplares impuestos por los poderes civiles a los que cometian tal delito. Este pasaba a la jurisdicción inquisitorial, cuando el procesado afirmaba que no era pecado la sodomía ${ }^{30}$.

27 AHN, Inquisición, leg. 1953, n. ${ }^{\circ} 31$, s.f. Causa n. ${ }^{\circ} 63$.

${ }^{28}$ Ibidem. Causa n. ${ }^{\circ} 65$.

29 Ibidem. Causa n. ${ }^{\circ} 64$.

30 TOMÁS Y VALIENTE, F., “El crimen y pecado contra natura", en Sexo barroco y otras trans- 
La hechicería hace su aparición en este auto en la persona de la veleña Francisca López, casada. En sus sortilegios, el culto al diablo se entremezcla con las alusiones a los apóstoles. A la encausada la acusaron seis testigos, porque "echava suertes con unas havas con invocaçion de demonios para saber si unos hombres querían bien a unas mugeres, y dava unos polvos conjurándolos con ynvocaçión de los apóstholes San Pedro, y San Pablo y Sanctiago para efecto de que los dichos hombres quisiesen bien a las dichas mugeres". En primera instancia fue apresada por los jueces reales, quienes ordenaron aplicarla tormento, en el cual confesó ser ciertas dichas hechicerías, así como «que ofreçió al demonio su alma y cuerpo, y tubo acçeso carnal con él».

Ante el cariz que tomaba el proceso, fue remitida a la justicia inquisitorial, por considerar que el delito era de su plena competencia. En el tribunal eclesiástico declaró que adoraba al diablo, el cual se la aparecía en forma de cochino, a quien le ofrecía todo su ser ${ }^{31}$. Con él mantuvo relaciones sexuales pero, al decir de la presa, copulaba con el demonio, no con ánimo de apartarse de la Iglesia, sino para que le concediese las cosas que le pedía. Fue votada a que saliese en auto público en forma de penitente con las insignias de hechicera y, leída su sentencia, abjurase de levi, se le diesen 100 azotes por las calles de Granada y, durante seis años, quedase desterrada de Granada y Vélez.

Un caso muy especial cierra la relación del auto de fe celebrado en 1606. Es el de Inés Arraval, esposa del escribano público de Ronda y, por tanto, perteneciente a la élite burocrática de la ciudad. La dama, en cuestión, había sido apresada por los jueces reales, acusada de adulterio

gresiones..., págs. 33-55. En las Partidas se recoge que el pecado nefando traía consigo una serie de males, entre los que estaban las enfermedades contagiosas, como la temida peste. Idea que se repite en la Pragmática de los RR.CC., emitida en 1497, donde se impone al infractor, además de la muerte en la hoguera, la confiscación de sus bienes. Para lograr la confesión del transgresor se aplicaba el tormento, aunque se tratase de un noble o clérigo. Los procesos se endurecen mediante la Pragmática dada por Felipe II, en tanto en cuanto se admite para enjuiciar al sodomítico un solo testigo. Esta legislación es incluida en la Nueva y en la Novísima Recopilación, por lo que seguiría vigente hasta principios del siglo xix.

${ }^{31}$ AHN, Inquisición, leg. $1953, n .^{\circ} 31$, s.f. Causa n. 61 . Es curiosa la figura con que se describe en este caso la aparición diabólica, que generalmente es en forma de macho cabrío u otro animal fantástico. No obstante, en los tratados de demonología aparece el cerdo relacionado con Satán. Unas veces, porque el demonio transporta a las brujas, a lomos de un cochino, para que asistan al aquelarre. En otras ocasiones, vemos a este animal acompañando a algunos diablos menores. Cfr. SALLMANN, J.M., Las brujas, amantes de Satán. Madrid, Ed. Aguilar, 1991, págs. 23 y 25. En el caso de Francisca López, la frontera entre el pecado de bestialidad, tan perseguido por la justicia real, y el de prácticas sexuales con el diablo, no queda aquí bien definido, al ser un cerdo con el que, al decir de la rea, tiene acceso carnal pensando que era Satán. 
por su esposo ${ }^{32}$. Falta considerada como muy grave tanto por la justicia seglar, como por la religiosa, ya que si la primera entendía de las ofensas que el marido recibía sobre su honra, la segunda perseguía el pecado que implicaba tal actitud por ir contra el sacramento del matrimonio ${ }^{33}$.

Un mundo de conjuros, hechizos, tesoros, apariciones, confusos rituales, profanaciones y antimisas, amenazas, intervenciones de la justicia real y de la inquisitorial, etc. se refleja en este famoso proceso, digno de novelarse por las fantasías o realidades fantaseadas, es difícil dilucidarlo, que se entremezclan. A todas estas apasionantes cuestiones, la figura de una gitana y de sus hechizos amoroso-criminales, así como la presencia de una alcahueta, ponen un curioso punto final a un suceso que, a todas luces, conmovería a la sociedad rondeña. $Y$ más, teniendo en cuenta que en él estuvieron implicadas personas pertenecientes al estamento concejil. Pero pasemos a analizar el proceso.

Al instruir el sumario de la causa, estando en la cárcel civil de la justicia real, la rea reclamó la presencia del comisario del Santo Oficio, porque quería delatar una serie de hechos que competian a esta institución. El comisario, la figura más representativa en Ronda del tribunal granadino, acudió con el notario inquisitorial nominado en la misma ciudad, para tomarle testificación. A partir de ese momento, son curiosas las declaraciones realizadas por la procesada, tal vez para desviar al tribunal de la Inquisición el juicio civil que, como adúltera, se había incoado contra ella. El dato nos indica que los procesos seguidos por este organismo religioso eran menos temidos que los seglares. De hecho, no es el primer caso de perseguidos por los tribunales del Rey, que desearan pasar a ser juzgados por los que estaban bajo la jurisdicción de la Suprema.

Comienza sus denuncias al Santo Oficio acusando de prácticas de brujería, profanaciones y antimisas al regidor Diego Núñez y a Doña Inés de Gamasa, esposa de Gaspar Vázquez, también miembro del regimiento del concejo rondeño, así como a otras personas del entorno de ambos. En una de las primeras audiencias testificó que la de Gamasa tenía en su domicilio un oratorio, en el cual había un altar y en él una figura pequeña de plata que representaba a un «hombre con dos corneçillos en la caveça". Asimismo, dijo que un día, vio acudir a la capilla al regidor Núñez, quien de forma ritual azotó a un Cristo. Además, observó que los concurrentes al acto tomaban un guiso cocinado con bayas de arrayán.

32 Ibidem. Causa n. ${ }^{\circ} 66$.

33 TOMÁS Y VALIENTE, F., op. cit., págs. 37 y 50 . A veces el marido ofendido tomaba la justicia por su mano y ejecutaba a la esposa, como hizo un escribano real de Madrid, en 1637. 
La delación fue por otros cauces y motivó que el comisario informase al tribunal de Granada sobre «que el dicho Diego Núñez era notorio confeso y a la dicha Inés Arraval le alcançava también parte». Aunque los calificadores no veian muy claro el delito de judaizantes, ambos fueron presos y sus bienes confiscados.

El proceso se complicaría porque en el ínterin llegaron a Ronda unos jueces de comisión que iban a proceder contra la rea, pues, según su propia confesión, había practicado la hechicería, junto con Inés de Gamasa y otras mujeres, para encontrar un tesoro escondido.

Se citaron varios testigos contestes, entre los que hace su aparición la gitana María Hernández, la cual afirmó que había ido con el grupo de féminas, hacia la media noche, a una mina cercana. Hemos de recordar que la opinión pública tenía a las gitanas, no sólo por adivinadoras, sino también por conocedoras de fórmulas mágicas, que se podían aplicar a fines más o menos peregrinos. A la entrada de la mina, hicieron unos cercos con velas encendidas y, para poder saber donde estaba el tesoro, comenzaron a invocar al espíritu que alli estaba prisionero, "diçiendo Christo y Dios, no os avemos menester a vos, que quien nos a de ayudar a su cargo lo tiene, que es la mora encantada Zafaybel». Tras este conjuro, vieron salir de la bocamina una figura como de muñeca, que rápidamente la cubrieron con un paño y se la llevaron, siguiéndoles en el camino de regreso una especie de sombra. No se especifica nada más acerca de la figura aparecida ni del intrincado tema. Tales hechos, ufueron calificados por hechicerias que sapiebant manifestam heresin y pacto cum demone».

Como en tales actos estaban involucradas mujeres de la oligarquía concejil rondeña y, además, las declaraciones de los testigos eran cada vez más confusas y contradictorias, se proveyó que un secretario del secreto hiciese una nueva información sobre Inés de Arraval y la gitana, que estaban en poder de los jueces de comisión. Ante él y el comisario no sólo se ratificaron en sus confesiones ambas mujeres, sino que la primera añadió que en casa de Inés de Gamasa hubo otra junta, en la que se celebró un ritual en el cual cada asistente, con una escoba mojada en sangre, azotaban a un cordero degollado. En tanto que se desarrollaba esa ceremonia, el tal Diego Núñez, que al parecer hacía las funciones de dirigente de la secta, mantenía la imagen de los "corneçillos". Finalizado el acto, colocó la escultura en un altar y se vistió de colorado. Después, llevó una especie de sagrada forma en una bandeja de estaño y la alzó al igual que lo hacen los sacerdotes en la consagración. Al mismo tiempo leía, en voz baja, un libro situado en el altar, en tanto que todos los presentes permanecían de rodillas. 
La ceremonia descrita refleja la celebración de una antimisa. ¿Se trata de cultos satánicos? La escultura de los cuernecillos recuerda la del demonio, pues aunque los acusados lo son por judaizar, es prácticamente imposible reconocer en esta figura la representación iconográfica de Moisés, ya que dicha religión prohibe el culto a las imágenes. Redundando en esto último, podemos citar cómo en el auto que estamos analizando, dos conversos son denunciados precisamente por no tener imágenes en sus casas, e incitaban a los demás para que tampoco las tuviesen. Por otra parte, el cordero degollado podría simbolizar a Jesucristo, a lo que se auna la profanación, real o simulada, de la sagrada forma.

Mientras el tribunal enjuiciaba todas estas acusaciones, denunciantes y denunciados estaban en prisión. Las primeras revocaron ante los representantes de la Inquisición sus testificaciones, afirmando que habían hecho tales declaraciones porque los jueces y escribanos reales las azotaron y aplicaron el tormento para que las dijesen. Además, las amenazaron de que si variaban sus confesiones ante los representantes locales del tribunal del Santo Oficio, cuando regresaran a sus cárceles las azotarían.

La rea, alegando siempre que había sido engañada por el demonio, incurrió en una serie de contradicciones. Unas veces acusaba de judaizantes a los susodichos Diego Núñez e Inés de Gamasa, pensando que por tal delación el Santo Oficio la eximiría de las culpas que pesaban sobre ella por el delito de adulterio, y la haría volver con su marido. Algo difícil de lograr, puesto que éste era quien había hecho los cargos contra ella, al parecer con bastante justificación, si se tiene en cuenta las declaraciones de la gitana que la acompañó en muchas de sus correrías.

En otras ocasiones, según el criterio de quienes la juzgaban, Inés de Arraval fantaseó algunas informaciones. Una de éstas fue la de que en una venta, se llegó a ella un hombre "cubierto el rrostro con un papahigo", especie de pasamontañas que no dejaba ver la cara, quien le hizo una serie de amenazas, si perseveraba en hablar de los tan debatidos judaísmos.

La poca fiabilidad de sus testimonios, junto con los cambios de opinión que alargaban el pleito indefinidamente, hizo que el comisario inquisitorial acordase comprobar de forma ocular, en unión del secretario del secreto y los familiares del Santo Oficio, si la procesada realmente pudo ver desde la puerta del oratorio todo lo que expuso en sus denuncias. Tras hacer las pruebas pertinentes, llegaron a la conclusión de que esto fue imposible.

Al mismo tiempo, se supo que uno de los jueces de la comisión había sido encarcelado en la Chancillería de Granada por haber falsificado, en 
unión del escribano de oficio, las declaraciones de los testigos. La corrupción judicial será otro aditamento que dio más morbo al caso. Pero esto no salvó a la de Arraval de que se la condenase a salir en el auto de fe con las insignias de revocante y perjura, además de aplicarla "çien azotes por las calles públicas» de Granada, y desterrarla perpetuamente, a la distancia de cinco leguas, de esa ciudad y de la de Ronda.

Las testificaciones de la gitana evidenciaron la infidelidad de la precitada rea, pues denunció «que para efecto de que la dicha Inés de Arraval matase a su marido y casase con su amigo, hizo otras hechicerías que fueron hazer en un huevo tres rrayas con un sarmiento sacado del fuego, y echarle en una olleta nueva con agujas y alfileres y agua bendita, haciendo çiertas invocaçiones en su lenga gitana, y ordenó al testigo que entre las doze y una de la noche, tiniendo la dicha olleta en la mano yzquierda, esperase tres ánimas que vernían haçiendo un cruçado, y que a la que se le pusiese a la mano yzquierda, le diese la olleta y la esperase otra noche a la misma hora, que vernía a hablar con ella y a deçirle todo lo que quisiese saber» ${ }^{34}$. Más tarde negaría lo confesado, motivo por el cual se le aplicará el mismo castigo que a la anterior procesada denunciada por ella, con la variante de ser desterrada sólo por dos años del distrito de la Inquisición granadina.

También hubo otro testigo que afirmó saber por una de las personas que iban a las juntas, protagonizadas por Diego Núñez Álvarez e Inés de Gamasa, que allí se daba culto a Moisés representado en una figura con unos cuernecillos dorados en las sienes, en cuyo altar el regidor leía un libro donde había "unas rrayas y figuras", al que escuchó palabras como "Sugorra y Gorroma», evidentemente se trataba de Sodoma y Gomorra. Sin embargo, no se dio crédito a estas denuncias, dado que quien las hacía era una "muger baxa y fue madre de la casa pública». Al descalificar sus declaraciones, así como las realizadas anteriormente por otras personas, a ambos procesados les fueron suspendidas sus causas, levantadas las confiscaciones $y$, por ende, puestos en libertad.

Es un tanto anómalo que las testigos mintiesen con tal serie de detalles. Pudieron exagerarlos, pero inventarlos, enlazarlos y ponerse de acuerdo resulta un tanto difícil de creer. El caso es muy confuso, y los

34 AHN, Inquisición, leg. $1953, n .^{\circ} 31$, s.f. Causa n. ${ }^{\circ} 67$. Los conjuros y recetas que las hechiceras solían hacer con fines de resolver problemas amorosos, en ocasiones tenían componentes bastante elementales, como el huevo, que también se cita en esta ocasión. Cfr. PÉREz Esconotado, J., Sexo e Inquisición en España. Madrid, Ed. Temas de Hoy. Colección Historia de la España sorprendente, 1992, págs. 124-140. 
cultos denunciados tienen más ribetes de brujería que de judaizantes. Sin embargo, no podemos olvidar que las celebraciones de los aquelarres eran asimismo denominadas del sabath o sábado, palabras muy relacionadas con el mundo judío. Además, era ya historia en esos tiempos, que cuando se desencadenaba una persecución antisemita, una de las primeras acusaciones que pesaban sobre ellos era la de sospechosos de brujería.

¿Qué hubo de verdad en los cargos imputados a Diego Núñez e Inés de Gamasa, entre ellos los de judaizantes? Es algo que los propios inquisidores no pudieron o no estuvieron inclinados a dilucidar; pero lo cierto es que en este auto no son objeto de persecución los conversos, dado el escaso número de procesados por dicha causa. Esto nos indica que la política de la Corona y, por tanto, del Santo Oficio no fuese en esos momentos por tales derroteros. Tal vez no se quería interferir en el desarrollo económico-mercantil que propiciaban los criptojudíos, quienes habían conseguido lograr una escalada social y ocupar una serie de puestos concejiles en diversos lugares del Reino de Granada, como sucedía en Ronda ${ }^{35}$. Por otra parte, el problema morisco era el más apremiante y su expulsión un hecho inminente, razones por las que recaerá sobre ellos casi todo el peso de la encarnizada persecución inquisitorial, al comenzar la centuria del Seiscientos.

Tras este enmarañado pleito, finaliza la relación de los procesados, con el caso del soldado Juan Jiménez de Maqueda, quien en Guadix atacó, e hirió levemente, al alguacil Mayor del Santo Oficio cuando intentaba prender a su compañero de armas. En descargo de tal osadía, argumentó que como el citado alguacil era también corregidor de Guadix, creyó que en el desempeño de dicho cargo, no como funcionario inquisitorial, iba a tomar prisionero a su camarada ${ }^{36}$. De nada le valieron sus escusas $y$, por tal desacato, que estaba muy próximo a ser un delito de fautoría, fue condenado a vergüenza pública y tres años en galeras ${ }^{37}$.

El análisis del auto de fe de 1606, una vez más nos pone de relieve las tensiones sociales existentes entre el mundo de los cristianos viejos

35 En Málaga encontramos en el siglo xvII varios judeoconversos como jurados del concejo: Pérez de Colosía Rodríguez, M. ${ }^{a}$ I., "La viña de Alonso Gamarra: centro del criptojudaísmo malagueño en el siglo xvil», Baetica, núm. 8 (1985), págs. 377-3.91.

${ }_{36}$ La acaparación de cargos en las plantillas locales del Santo Oficio era algo que estaba al orden del día. En Málaga encontramos familiares, alguaciles y notarios que ocupaban otros puestos en los concejos, en las milicias y en las escribanías públicas: PÉREz de Colosía RoDriguez, M. '., "Documentación inquisitorial en los Libros de Provisiones: 1650-1700", Baetica, núm. 14 (1992), págs. 253-272.

37 AHN, Inquisición, leg. $1953, \mathrm{n} .^{\circ} 31$, s.f. Causa n. ${ }^{\circ} 70$. 
y de los moriscos. Las sentencias emitidas en esta ceremonia punitiva, demuestran el fracaso de la aculturación de los mudéjares convertidos ${ }^{38}$. Si a esto añadimos que a principios del siglo XVII, los neoconversos aún persistían en sus prácticas religiosas islamizantes, así como en sus usos y costumbres, encontramos que la separación entre las culturas de los vencedores y vencidos se hizo cada vez mayor. Un auténtico abismo de encontradas ideologías y tradiciones les enfrentaban, hasta el punto que llevó a Felipe III a tomar una controvertida decisión: la definitiva expulsión de los moriscos del territorio peninsular.

38 Gil Sanjuan, J., Ofensiva final antimorisca..., págs. 191-194. 